BIBLID: 0015-1807, 47 (2020), 2 (pp. 89-95)

UDK 821.162.4.09 Harpanj M.

821.162.4(497.11):929 Harpanj M.

https://doi.org/10.18485/fpregled.2020.47.2.6

\author{
Marina Šimakova Spevakova \\ Univerzitet u Novom Sadu - Filozofski fakultet \\ marina.simak@ff.uns.ac.rs
}

\title{
OBLICI SLOVAČKE KNJǏ̌EVNOSTI I NAUKE O KNJIŽEVNOSTI U DELU MIHALA HARPANJA
}

\begin{abstract}
Apstrakt: Cilj rada je da se kroz pregled izuzetno bogatog rada Mihala Harpanja, univerzitetskog profesora u penziji, književnog naučnika i prevodioca, ukaže na one različite aspekte u njegovoj delatnosti u kojima je ostvario najveći uticaj na slovačku književnost u Srbiji. Posebnu pažnju posvetićemo Harpanjevom kritičkom, teorijskom i prevodilačkom radu u kontekstu nadovezivanja na moderni strukturalizam i semiotiku sa posebnim osvrtom na vrednovanje rada profesora Harpanja u Slovačkoj i u slovačkim sredinama u Rumuniji, Mađarskoj i Srbiji. Zahvaljujući priznavanju njegovog rada van granica Srbije, profesor je slovačku književnost u Vojvodini (Srbiji) učinio vidljivijom u širem kontekstu, dok prevodilačkim radom na srpski jezik doprinosi da moderna slovačka nauka o književnosti i savremena slovačka proza budu dostupne srpskoj književnosti.
\end{abstract}

Ključne reči: Mihal Harpanj, slovačka književnost, teorija književnosti, strukturalizam, prevod.

Mihal Harpanj, redovni profesor slovačke književnosti i nauke o književnosti na Filozofskom fakultetu u Novom Sadu u penziji i doctor honoris causa na Univerzitetu „Matej Bel” u Slovačkoj Republici, 27. oktobra 2019. navršava 75 godina života. Najveći deo izuzetno bogatog radnog veka proveo je u pedagoškom radu sa studentima slovakistike, objavio je veliki broj knjiga, studija, eseja, monografija na slovačkom i srpskom jeziku, dok se u aktuelnom stvaralačkom periodu najviše bavi prevodima savremene slovačke proze i književne teorije. U profesorovom višedecenijskom radu u oblasti književnosti i nauke o književnosti podjednako su zastupljena i funkcionalno isprepletena sva tri polja književne nauke: kritika, istorija i književna teorija. Prirodni afinitet prema književnosti u simbiozi sa književnonaučnim i pedagoškim autoritetom uticali su na oblikovanje identiteta slovačke književnosti u Jugoslaviji i Srbiji.

Književnonaučni rad profesora Mihala Harpanja otpočeo je na studijama jugoslovenskih književnosti na Filozofskom fakultetu Univerziteta u Novom Sadu. Još kao student, Harpanj je prvi put posetio Slovačku 1967. godine u okviru Letnje škole slovačkog jezika i kulture (SAS), kada je na podsticaj svog budućeg dugogodišnjeg prijatelja i saradnika Milana Šutovca (1940) objavio i svoj prvi književni tekst u Slovačkoj. Neposredno posle završetka studija, M. Harpanj se zaposlio na Katedri za slovački jezik i književnost na Filozofskom fakultetu, 
gde je stekao zvanje redovnog profesora. Ime profesora Harpanja nalazi se među najznačajnijim ličnostima Katedre za slovački jezik i književnost, kasnije Odseka za slovakistiku jer je kao dugogodišnji rukovodilac, do odlaska u penziju 2013. godine, učestvovao u njegovom profilisanju, uticao na formiranje mnogobrojnih budućih profesora slovačkog jezika i književnosti, novinara, istraživača koji i dan-danas svojim radom daju doprinos kulturnom životu Slovaka u Republici Srbiji. Treba pomenuti da je profesor M. Harpanj predavao Slovačku književnost i Teoriju književnosti na Filološkom fakultetu u Beogradu, na Visokoj pedagoškoj školi u Segedinu, na Pedagoškom fakultetu u Somboru - detaširanom odeljenju u Bačkom Petrovcu, kao i na Filozofskom fakultetu Univerziteta „Matej Bel” u Banskoj Bistrici u Slovačkoj Republici, gde mu je u novembru 2012. godine dodeljen počasni doktorat.

U fokusu književnonaučne delatnosti Mihala Harpanja nalazi se savremena slovačka književnost, slovačka književnost u Vojvodini, južnoslovensko-slovačke kulturne i književne veze i teorija književnosti. Od samih početaka Harpanj je svoj rad zasnivao na tradicijama češkog strukturalizma i semiotike a po uzoru na šire poznatu slovačku njitransku školu, vođenu Františekom Mikom i Antonom Popovičem, koje je lično poznavao. Temeljno poznavanje rada Mike i Popoviča ogleda se i u Harpanjevim izborima iz njihovih dela, prevodima kako pojedinih studija tako i njihovih knjiga u punom obimu na srpski jezik. Osim toga, Harpanj je informisao jugoslovensku i pre svega srpsku naučnu javnost o slovačkoj i češkoj književnoj teoriji (o Janu Mukaržovskom, Jiržiju Leviju, Mikulašu Bakošu, Peteru Zajacu) u referatima na naučnim konferencijama. Najsistematičnija primena strukturalističke analize prisutna je u Harpanjevoj knjizi Poezija i poetika Mihala Babinke (Poézia a poetika Michala Babinku, 1980), u kojoj precizno vivisecira poetiku do tada „nerazumljivog” pesnika Mihala Babinke, čime je doprineo etabliranju ovog autora u sam vrh slovačke vojvođanske književnosti, ali i njegovom prihvatanju u književnosti u Slovačkoj. Jedan od pokazatelja Babinkine prihvaćenosti u Slovačkoj jeste knjiga izbora iz njegove poezije pod nazivom Sviatok jazier (1999) Vilijama Marčoka (19352013), jednog od najuticajnijih književnih kritičara druge polovine 20. veka u Slovačkoj. Metodološki doslednu analizu odnosa paradigmatskih i sintagmatskih delova unutar dinamičnog sistema književnog teksta imaju i naratološki tekstovi Promene pripovedanja (Premeny rozprávania, 1990), zbirka eseja $O$ Palju Bohušu (O Pal'ovi Bohušovi, 1999), izbor studija objavljen u Bratislavi Tekstovi i konteksti (Texty a kontexty, 2004) i knjiga Teorija književnosti u više izdanja (Teória literatúry, 1986, 1994, 2004, 2009).

Sveobuhvatnost rada Mihala Harpanja, kao deo za celinu, predstavlja i jedan od izbora iz njegovog dugogodišnjeg istraživačkog i naučnog rada u knjizi studija Poglavlja iz slovačke književnosti i nauke o književnosti (Matica srpska, 2019). Izbor obuhvata dvadeset dve studije pisane na srpskom jeziku (i $\mathrm{u}$ autorovom prevodu na srpski jezik) koje su funkcionalno namenjene informi- 
sanju srpskih čitalaca o slovačkoj književnosti, kao i aktuelnim i najznačajnijim teorijskim istraživanjima u oblasti slovačke književne nauke. Kroz tri tematska bloka može se pratiti Harpanjevo teorijsko uopštavanje manjinske književnosti (Manjinske književnosti i interliterarni procesi), interpretacija konkretnih književnih ostvarenja pisaca manjinske književnosti (Mihala Babinke, Palja Bohuša, Vićazoslava Hronjeca), analitičko-interpretativne studije o savremenoj slovačkoj postmodernističkoj prozi (Društvena sredina i epski prostor), komparativne studije o tipološkim karakteristikama slovačke i srpske književnosti (Novi pokušaj o Vaska Popu i Jana Ondruša). Interpretativno i kritički bogata knjiga završava se studijom o razvojnim aspektima moderne i savremene slovačke teorije književnosti od tridesetih godina 20 . veka do današnjih dana, te posebnim prikazom rada teoretičara koji su poznati i u širem evropskom kontekstu (J. Mukaržovski, M. Bakoš, F. Miko, A. Popovič, P. Zajac).

Veliki deo stvaralačke i naučne delatnosti Mihal Harpanj posvetio je definisanju identiteta slovačke književnosti u našoj zemlji. U traženju adekvatnog teorijskog okvira za specifične okolnosti nastajanja i razvijanja slovačke književnosti u stranom prostoru, Harpanj nikad nije gubio iz vida pripadnost ove književne zajednice celoslovačkoj književnosti. Adekvatnu platformu za svoja istraživanja našao je u teorijskom konceptu Dioniza Đurišina o interliterarnim zajednicama, čiji je razvojni put predočio u svojim studijama kroz prikaz nekoliko kapitalnih ostvarenja ovog najznačajnijeg slovačkog komparatiste. Nakon tumačenja koncepcije interliterarnosti, Harpanj je kritički primenio Đurišinovu teoriju u definisanju manjinskih književnosti kao višekontekstualnih interliterarnih zajednica. Treba naglasiti da je pomenuta Harpanjeva koncepcija prihvaćena i primenjivana u interpretacijama slovačkih manjinskih književnosti u Srbiji, Mađarskoj i Rumuniji, a njen teorijski koncept više puta je citiran u savremenim istraživanjima akademske kritike u Slovačkoj (na primer u monografiji Konteksti slovačke moderne Dane Hučkove). U svojim komparatističkim studijama bavio se kritičkom primenom Đurišinove koncepcije, kao u studiji o tri manjinska autora iz različitih manjinskih sredina - Lajoš Grendel, mađarski pisac u Slovačkoj, Pal Zavadi, mađarski pisac koji piše o slovačkoj manjini u Mađarskoj, te Vićazoslav Hronjec, slovački autor koji stvara u Srbiji. Preplitanje teorijskog okvira i interpretativne prakse u studijama i esejima najbolje ilustruju Harpanjevu povezanost sa tradicijom slovačke moderne strukturalističke misli, ali i njegovu originalnu nadogradnju kroz vlastiti koncept. Od monografija na slovačkom jeziku, posebno se manjinskom književnošću i njenim teorijskim utemeljenjem bavio u knjigama Tekstovi i konteksti (Texty a kontexty), Borba za identitet (Zápas o identitu), Ars poetica Pannonica, Scripta menent i dr. Svojim književnonaučnim radom Mihal Harpanj je pre svega uticao na oblikovanje slovačke književnosti u Srbiji, najviše sopstvenim primerom podsticao njenu recepciju u Slovačkoj i srpskom literarnom kontekstu. Veoma značajan doprinos recepciji slovačke enklavne književnosti koja nastaje izvan granica Slovačke, takozvane slovačke donjozemske književnosti u 
Rumuniji, Mađarskoj i Vojvodini, dao je upravo profesor Harpanj uspostavljanjem teorijskog ishodišta o njenoj višekontekstualnoj suštini.

U pomenutoj knjizi Tekstovi i konteksti (Texty a kontexty, 2004), koja se smatra jednim od najznačajnijih pokazatelja priznanja Harpanjevog književnonaučnog rada u Slovačkoj, Milan Šutovec u predgovoru ovoj knjizi ističe autorov doprinos teoriji književnosti:

Njegovo nekadašnje obrazovanje zasnovano na dobrim autorima strukturalističke i poststrukturalističke orijentacije i njegovo interpretativno i pedagoško iskustvo su mu dozvolili da preduzme korak, na koji se ovde u Slovačkoj u takvoj meri niko nije usudio: napisao je i do sada u tri izdanja objavio Teoriju književnosti $(1986,1994$, 2004), koja je jedino sintetičko delo ove vrste u modernoj slovačkoj nauci o književnosti i (prema mojim saznanjima) jedina slovačka teorija književnosti koja se danas koristi u funkciji standardnog priručnika na visokoškolskim studijama književnosti. ${ }^{1}$

I danas je Harpanjeva Teorija književnosti u osnovi predavanja o stilističkim, versifikacijskim, žanrovskim i metodološkim pristupima književnosti. Uz primerenu konfrontaciju sa novim tokovima i književnonaučnim metodama, ovaj priručnik je i dalje od važnosti studentima slovakistike kada je u pitanju studij slovačke književnosti.

Prevodilački rad profesora Mihala Harpanja otpočeo je šezdesetih godina, kada je najpre srpskim čitaocima predstavio poeziju Mihala Babinke i Vićazoslava Hronjeca, pored Palja Saba Bohuša dva najznačajnija pesnika Slovaka koji žive i stvaraju u Srbiji. Usledio je ubrzo i prevod teksta savremenog slovačkog prozaiste Pavela Vilikovskog, kojeg je prvi put upoznao u Novom Sadu kao student jugoslovenskih književnosti. Vilikovski je zajedno sa M. Šutovcem bio u poseti redakciji Letopisa Matice srpske kada su ih Aleksandar Tišma i Boško Petrović upoznali sa M. Harpanjem. Interesovanje za prevođenje dela Vilikovskog kod Harpanja traje kroz lično prijateljstvo i saradnju na novim književnim prevodima do današnjih dana. Od savremenih slovačkih pisaca Pavel Vilikovski je najprevođeniji pisac na srpski jezik upravo zahvaljujući prevodilačkom radu Harpanja. Prvi prevod pripovetke P. Vilikovskog objavljen je pod nazivom Susreti: od ljubavi ka ljubavi novoj u Letopisu Matice srpske 1968. godine, usledili su prevodi knjiga krajem devedesetih godina 20. veka: Konj na spratu, slepac u gradu (1997), zbirka pripovedaka Surovi mašinovođa (2000), roman Poslednji konj Pompeja (2002 i 2013, kada je objavljena u Ediciji 100 slovenskih romana), Čarobni papagaj i preostali kič, 2015). Proza Pavela Vilikovskog više puta je nagrađivana najvišim literarnim priznanjima u Slovačkoj, visoko je vrednuje savremena kritika u Slovačkoj i van nje, a autor je poznat kao poznavalac jezika i vrstan stilista, čije delo obiluje intertekstualnim relacijama, te prevodiocima

${ }^{1}$ Harpanj, M. (2004): Texty a kontexty, Bratislava, LIC, s. 11. Sa slovačkog prevela M. Š. S. 
predstavlja izazov. ${ }^{2}$ Pored Vilikovskog, od savemenih slovačkih autora, Mihal Harpanj je preveo pripovetke i roman Dušana Mitane, Dušana Kužela, a posebnu vrednost ima antologija kratke slovačke proze Crna boja radosti (2016).

Treba pomenuti i Harpanjevo prevođenje slovačke nauke o književnosti. Izbor i prevod iz dela Antona Popoviča, Estetska metakomunikacija (2018) jedan je u nizu profesorovih prevoda moderne slovačke nauke o književnosti na srpski jezik, pored izbora i prevoda dela Františeka Mike (Delo, komunikacija, kultura, Narodna knjiga, 1998. i Prolegomena za semiotiku bića, Službeni glasnik, 2016), izbor i prevod koncepcije pulsacione estetike Petera Zajaca (Pulsiranje književnosti, Izdavačka knjižarnica Zorana Stojanovića, 2015), kao i knjige Modeli i diskursi nauke o književnosti (Službeni glasnik, 2018) koju čini izbor iz moderne slovačke nauke o književnosti od tridesetih godina 20. veka do danas. Književnonaučno i teorijsko sazrevanje Popoviča sagledava se u kontekstu razvoja strukturalizma u Slovačkoj šezdesetih godina, u okolnostima oslabljenih restriktivnih ideoloških mera. Popovičevo zalaganje za strukturalizam, prema Harpanju, značajno je i u širem kontekstu. On je skrenuo pažnju na način, na koji je deo mladih naučnih istraživača raskidao veze sa tradicionalizmom, prisutnim tridesetih godina prošlog veka u nauci, indirektno ukazujući na Popovičevo opredeljenje za put nastavljača one tradicije, koja se oslanjala na scijentistički pogled i metod, nasuprot pozitivizmu i folklorizmu. Monografija Estetska metakomunikacija prikazuje najznačajnije studije iz oblasti Popovičeve teorije umetničkog prevođenja u koju je ovaj autor integrisao širu problematiku književne komparatistike, sociologije književnosti i istorijske poetike. Sintetički izbor iz književnoteorijskog dela Františeka Mike, njihov prevod na srpski jezik i pogovor načinio je Mihal Harpanj u pomenutim knjigama Delo, komunikacija, kultura (1998) i Prolegomena za semiotiku bića (2016). One približavaju Mikovo teorijsko mišljenje zasnovano na razvoju originalne teorije sistema kategorija izraza kao „funkcionalne aspekte stila kojima odgovaraju određeni jezički i tematski elementi u strukturi teksta". ${ }^{3}$ Okosnica strukture Mikovih tekstova jeste komplementarnost teorijskog i interpretativnog dela koji se u međusobnoj interakciji dopunjuju i modifikuju. Ovaj teorijsko-interpretativni model književnoteorijskog pristupa, osnovno je polazište i inspiracija za istraživanja u slovačkoj teoriji književnosti i danas, na šta ukazuje i izbor iz novije slovačke nauke o književnosti Modeli i diskursi nauke o književnosti (2018), kao i knjiga Petera Zajaca Pulsiranje književnosti (2015). Peter Zajac u svojoj književnoteorijskoj misli nastavlja u najopštijim okvirima tradiciju Mikove škole, što podrazumeva kreiranje teorije koja se ne samo prožima, već i dopunjuje i modifikuje uz pomoć interpretacija konkretnih tekstova svetske i slovačke književnosti. Osnovne teorijske postavke misli P. Zajaca, međutim, prevazilaze

${ }^{2}$ Delu Pavela Vilikovskog i aspektima njegovog prevoda na srpski jezik posvetili smo detaljniju pažnju u studiji Međuknjiževne veze u prozi slovačkog autora Pavela Vilikovskog iz ugla recepcije $i$ prevoda (Književna istorija, 2019).

${ }^{3}$ Miko, F. (2016): Prolegomena za semiotiku bića, Beograd, Službeni glasnik, str. 202. 
polazišta strukturalizma i semiologije u pravcu prirodnih nauka u simbiozi sa književnom teorijom. Mihal Harpanj u iscrpnom pogovoru objašnjava ovo prožimanje: „Nauka o književnosti, dakle, i to pre svega njena teorijska dimenzija, ponovo treba da se okrene prirodnim naukama, ali sad onim njihovim saznanjima koja su bila podstaknuta hipotezama iz oblasti duhovne spoznaje. Zajac tu pre svega misli na teoriju sistema i na sinergetiku kao naučnu disciplinu koja se bavi 'kooperacijom između pojedinih delova sistema"'.

U ranijim tekstovima o slovačkoj nauci o književnosti u srpskom kontekstu zaključili smo da Mihal Harpanj svojim književnonaučnim i prevodilačkim radom podjednako pripada slovačkom i srpskom književnom kontekstu i da se suština njegovog rada može nazvati biliterarnom. Pojam biliterarnosti tumačimo u skladu sa shvatanjem Dioniza Đurišina i on se odnosi na preklapanje dva ili nekoliko književnih sistema, tradicija i konvencija. Ravnopravno profesionalno i životno angažovanje u dva konteksta su profesoru Harpanju omogućile studije jugoslovenskih književnosti, kao i delovanje na Univerzitetu u Novom Sadu na maternjem slovačkom jeziku, pri čemu je stvarao jedinstveni međuprostor interliterarnog prožimanja. Na to ukazuju kako Harpanjeve ranije kritike o srpskoj književnosti tako i komparativne studije, od kojih posebno izdvajamo tekstove: Poetska struktura Nastasijevićeve proze, Tuga i opomena: fragmenti o poeziji Branka Miljkovića, Tipološke relacije slovačkog i srpskog nadrealizma, Manjinske književnosti i interliterarni procesi, komparativna studija o poeziji Vaska Pope i Jana Ondruša, Srpsko-slovačke kulturne i književne veze, Slovačka književnost u književnim kontekstima, Recepcija književnog dela Milorada Pavića u slovačkoj književnosti, Metatekst kao model međutekstovnog nadovezivanja.

Milan Šutovec je u predgovoru knjizi Tekstovi i konteksti konstatovao da slovačka nauka o književnosti i slovačka književnost odavno znaju da kod profesora Mihala Harpanja imaju svog legitimnog pripadnika kao što ga imaju i Slovaci u Vojvodini, kao i u rumunskoj, hrvatskoj i mađarskoj okolini. Pored svega do sada pomenutog, Mihal Harpanj u sadašnjosti priprema novi izbor iz svog književnonaučnog rada i ujedno radi na prevodu nove knjige savremene slovačke proze na srpski jezik.

\section{LITERATURA}

Harpanj, Mihal, Texty a kontexty, Bratislava, LIC, 2004.

Harpanj, Mihal, Modeli i diskursi nauke o književnosti. Izbor iz novije slovačke nauke o književnosti, Beograd, Službeni glasnik, 2018.

Harpanj, Mihal, Poglavlja iz slovačke književnosti i nauke o književnosti. Novi Sad, Matica srpska, 2019.

${ }^{4}$ Зајац, П. (2015): Пулсирање књижевности, Сремски Карловци, Издавачка књижарница Зорана Стојановића, стр. 338. 
Marina Šimakova Spevakova, Oblici slovačke književnosti i nauke o književnosti u delu ... 2016.

Miko, František, Prolegomena za semiotiku bića, Beograd, Službeni glasnik,

Popovič, Anton, Estetska metakomunikacija, Beograd, Službeni glasnik, 2018.

Зајац, Петер, Пулсирање књижевности, Сремски Карловци, Издавачка књижарница Зорана Стојановића, 2015.

Marina Šimakova Spevakova

\section{FORMS OF SLOVAK LITERATURE AND LITERARY THEORY \\ IN THE WORKS OF MICHAL HARPÁŇ}

(Summary)

The paper deals with the rich work of Michal Harpán̆, literary scholar, translator and retired university professor. We point out the importance of his critical adherence to the concept of D. Durisin's interliteracy for Slovak literature in Serbia as well as in Romania and Hungary. In the Slovak Republic, Professor Harpáň's most significant work is in the field of literary theory, and his textbook is widely used in the universities. We can point out Harpan's translation work of modern Slovak literary theory into the Serbian language, which enabled the most significant works of A. Popovič, F. Miko and P. Zajac to be available in Serbia.

Keywords: Michal Harpán̆, literary theory, structuralism, translation, Slovak literature.

Примљено 23. октобра 2019, прихваћено за објављивање 10. децембра 2020. године. 